\title{
Experts, Refugees, and Radicals: Borders and Orders in the Hotspot of Crisis
}

\author{
Anna Carastathis ${ }^{1}$ and Myrto Tsilimpounidi ${ }^{2}$
}

In July 2016, we participated in a conference in Lesvos (Greece) on borders, migration, and the refugee crisis. The Crossing Borders conference was framed in contrast with the ad-hoc humanitarianism that was being implemented, to the extent that it seemed to offer an opportunity to think about the refugee crisis, militarism, and austerity capitalism in systemic terms. This paper is based on an intervention we staged in the closing panel of the Crossing Borders conference, where we read a statement we collectively wrote with fourteen other participants. The intervention was the outcome of frustration as we saw stereotypes and dynamics of knowledge production that reproduced the division between "us" and "them," further marginalising migrants and refugees, elevating international experts while silencing locally affected people. We use this incident and the text of this intervention as a starting point to analyse the growing academic industry in relation to what has been constructed as "Europe's refugee crisis." Our intervention sought to contest several kinds of borders-linguistic, epistemic, activist, methodological, political, historical, and internalisedwhich are uncritically reproduced in this academic industry. [Article copies available for a fee from The Transformative Studies Institute. E-mail address: journal@transformativestudies.org Website: http://www.transformativestudies.org (C2018 by The Transformative Studies Institute. All rights reserved.]

KEYWORDS: Hotspot, Radical Scholarship, Crisis, Lesvos.

\footnotetext{
${ }^{1}$ Anna Carastathis is a Postdoctoral Researcher, Department of Social Anthropology, Panteion University (Athens). Her Ph.D. is in political philosophy from McGill University and holds a M.Sc. in gender studies from the University of the Aegean. Carastathis has held research and teaching positions in various universities in the United States and Canada. She is the author of Intersectionality: Origins, Contestations, Horizons (University of Nebraska Press, 2016). Her current research examines the crises produced by the war on migration as it articulates austerity capitalism, focusing on the Aegean sea crossing in the eastern Mediterranean. Anna lives in Athens. Address correspondence to: Dr. Anna Carastathis; e-mail: acarastathis@gmail.com.

${ }^{2}$ Myrto Tsilimpounidi is a social researcher and photographer. Her research focuses on the interface between urbanism, culture, and innovative methodologies. She is the author of Sociology of Crisis: Visualising Urban Austerity (Routledge, 2016), co-editor of Remapping Crisis: A Guide to Athens (Zero Books, 2014), and Street Art \& Graffiti: Reading, Writing \& Representing the City (Routledge, 2017). Myrto is the co-director of the Ministry of Untold Stories and a Marie Curie Fellow at the Institute for Sociology of the Slovak Academy of Sciences.
} 